\title{
II. THE GREAT ENTRANCE
}

\section{Liturgy of the Catechumens}

After the Vespers, the ordinance of the Presanctified Liturgy is continued with the Litany of Fervent Supplication ("Let us all say..."). Then, before the Great Entrance, there follow the prayers and the Litany of the Catechumens, Prayers and Litany for those Preparing for Enlightenment (baptism), two Prayers and the Litany of the Faithful, and the exclamation, "According to the gift of your Christ..." These parts of the ordinance are present already in the earliest Euchologion Barberini 336 (8th C.). ${ }^{93}$ The specific feature of the initial part of the Presanctified Liturgy from the service books of the Old Russian recension is the absence of the Prayer and the Litany for those Preparing for Enlightenment in most manuscripts. ${ }^{94}$ The Prayer "Manifest your countenance, Master..." and the Litany "As many as are preparing for Enlightenment..." are found in only four out of sixteen manuscripts: ${ }^{95}$ Sol. 1016/1125, Sof. 519, Syn. 598, and YaMZ 15472. ${ }^{96}$ In some Greek Euchologia, the Prayer for those Preparing for Enlightenment is either missing, or bears a different name. ${ }^{97}$ Thus, the Barberini 336 contains the text of the prayers of the Presanctified Liturgy on fol. $37 \mathrm{r}-$ fol. $43 \mathrm{v}$, and, separately, the Litanies at fol. $260 \mathrm{v}-$ fol. 262r. In the series of prayers, the text of "Manifest your countenance, Master..." is called the

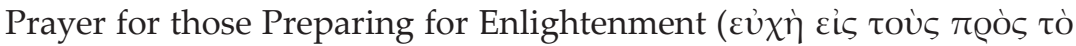

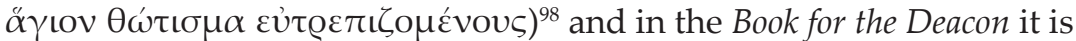

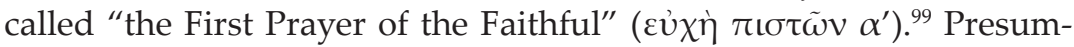
ably, such a record in the Greek protograph resulted in the fact that the

(93) Parenti, Velkovska, L'eucologio Barberini..., 42-48, 310-314.

(94) All other Slavonic manuscripts of the Presanctified Liturgy that date to the thirteenth - fourteenth centuries and do not belong to the Old Russian recension, contain both the Prayer and the Litany for those Preparing for Enlightenment.

(95) Here we speak about 16, and not 17 manuscripts, since part of the pages from the manuscript O.p. I.4, that contain the ordinance of the Presanctified Liturgy, are missing, specifically, the pages on which the Litany and the Prayer for those Preparing for Enlightenment might have been written.

(96) Prayer for those Preparing for Enlightenment is also present in the service book Syn. 604, but the corresponding Litany is absent.

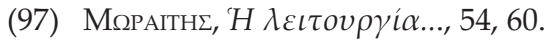

(98) Parenti, Velkovska, L'eucologio Barberini..., 42.

(99) Ibid., p. 312. 
service book Syn. 604 contains only the Prayer for those Preparing for Enlightenment, and the Litany for those Preparing for Enlightenment is missing. With all that, the Litany of Peace for the Faithful ("Again and again, in peace let us pray to the Lord...") is shown twice in the text of the Liturgy: the first time after the Prayer for those Preparing for Enlightenment, and then, at its usual place after the Prayer for the Faithful.

Another specific feature of the initial part of the Liturgy is the presence of two additional petitions in the initial Litany of the Liturgy of the Catechumens in the manuscripts Sof. 525, Syn. typ. 40: че молӥс А

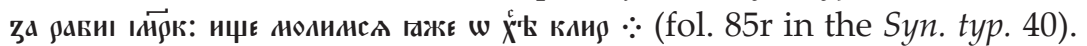
The second of these petitions, which is absent in the modern service, is also present in the Syn. 598. In addition, after the exclamation "For you, O God, are merciful..." that finishes the first Litany, the Syn. typ. 40, 1. 85 contains a short Litany for the Dead with a regular exclamation raкo ты єси ѓn покои । животь $\because$

\section{Prayers of the Great Entrance}

All service books of the Old Russian recension contain a reference to the singing of the Hymn "Now the hosts of heaven invisibly worship..." during the Great Entrance. Most manuscripts provide only the opening words, while the full text is contained only in the Sof. 525 and Syn. typ. 40. We should note that there exists some archaeological material, containing the text of "Now the hosts of heaven invisibly worship..." from the same period as the service books of the Old Russian recension. This is the fragment of old frescoes from two churches, of St. Clement and of the Savior, discovered in the last century during the excavations in Staraya Ladoga. ${ }^{100}$ The modern Slavonic text of "Now the hosts of heaven invisibly worship..." has a lexical different reading from the Greek text: "fear-love." The manuscripts Sof. 525 and Syn. typ. 40, following the Greek original, include the reading "fear," as well as the service books Q.p. I.68, Čorovič 7, and the inscription from Staraya Ladoga. ${ }^{101}$ However, the reading "love" was already quite widespread in the fourteenth

(100) Н. Е. БРАНДЕНБург, Археологические исследования в Старой Ладоге 1886-1887 22. (Санкт-Петербург, 1887).

(101) On the inscription, see: Т. В. РОждествеНская, Типы эпиграфических текстов в надписях Древней Руси XI-XV вв. (Новгород, Киев, Ладога, Галич), Die Slawischen Sprachen 28 (1991) 122-124; ОНА жЕ, Богослужебные тексты в церковной эпиграфике древней Руси, Византинороссика 1 (1995) 303-311. 
century service books, for example, in the O.p. I.48, Dečani 119-123, Krušedol Zh IV64.

According to the modern service books, the Great Entrance begins with burning incense at the Holy Gifts. While burning incense, the priest recites Psalm 50. ${ }^{102}$ The publisher of the Greek texts Muraitis refers to the Codex of the turn of the thirteenth-fourteenth centuries, Sinai 971, as the earliest Euchologion mentioning the reading of Psalm 50 at the Great Entrance of the Presanctified Liturgy, ${ }^{103}$ but the reference to Psalm 50 can be found in all the manuscripts of the Old Russian recension, which confirms the antiquity of pronouncing this Psalm at the Great Entrance. In the Euchologia of the twelfth century from the National Library of Athens № 662 and № 713, there are instructions for not pronouncing the "Cherubim prayer," that is, the prayer, required for reading during the Great Entrance at the Liturgy of John Chrysostom. However, a number of Euchologia contain a contrary indication. In particular, the manuscript of the thirteenth century Sinai 982 cites the first words of this prayer "No one bound by worldly desires and pleasures is worthy..." during the Great Entrance of the Presanctified Liturgy. ${ }^{104} \mathrm{~A}$ rubric with the same content is present in the service book

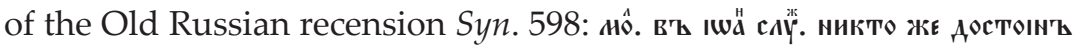
свазавйис (fol. 61v). ${ }^{105}$ The instruction on including the prayer from the Liturgy of John Chrysostom into the ordinance of the Great Entrance during the Presanctified Liturgy corresponds to the general trend of

(102) Чин Божественныя литургии Преждеосвященных Даров во Святую и Великую Четыредесятницу, in: Служебник, ч. 2 (Москва, 1991) 425.

(103) M M

(104) Ibid.

(105) Slavonic service books of the thirteenth-fifteenth centuries, in addition to "No one bound by worldly desires and pleasures is worthy...," contain the instructions on reading the Prayer "O God, sitting on the Cherubim and Glorified by the Seraphim..." (Khlud. 117, Uvar. 46, Syn. typ. 40, Syn. typ. 43 and others, see, p. 39), as well as the Prayer "Master and Lord, who visit us in mercy and com-

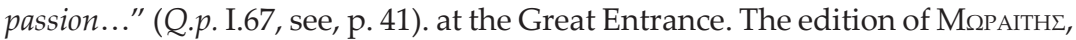

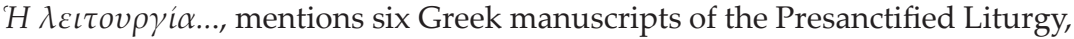
that have the Prayer "Master and Lord, who visit us in mercy and compassion..." (see, note 116). In the Greek Euchologia, the Prayer "O God, who in mercy and compassion hast looked upon our humility..." from the Liturgy of Basil the Great can be found in the Sinai 971 (13th-14th C.), and the Philotheos Monastery on Mount Athos № 177 (1332) - seе: Дмитриввский, Описание литургических рукописей..., т. 2, 250, 270. 
introducing liturgical elements from the Liturgy of John Chrysostom and Basil the Great into the Liturgy of the Presanctified Gifts, already noted by Uspensky. ${ }^{106}$

The manuscripts Khlud. 117 (fol. 48v - fol. 49r) and Uvar. 46 (fol. $82 \mathrm{v}-$ fol. $83 \mathrm{r}$ ), and the service books of the Old Russian recension Syn. typ. 40 (fol. 88v - fol. 89r) and Syn. typ. 43 (fol. 69r - fol. 69v) contain the Prayer at the Great Entrance "O God, sitting on the Cherubim and Glorified by the Seraphim...," made by the priest. This prayer is not found in other manuscripts of the Presanctified Liturgy of the thirteenth-fifteenth centuries. ${ }^{107}$ We do not know Greek manuscripts of the Presanctified Liturgy that contain the Prayer "O God, sitting on the Cherubim and Glorified by the Seraphim..." However, this Prayer can

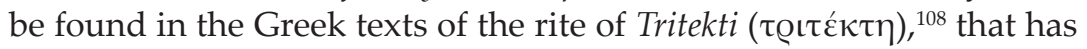
disappeared now, as well as in the texts of the First Hour of the "asma-

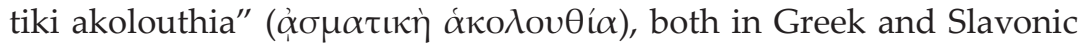
sources. ${ }^{109}$

In the service book Syn. typ. 40, the Prayer "O God, sitting on the Cherubim and Glorified by the Seraphim..." is entitled "мй в пєєєосъ". In the Khlud. 117, and in the Uvar. 46 and Syn. typ. 43, the Prayer does not have a title, but the position of "O God, sitting on the Cherubim and Glorified by the Seraphim..." in the ordinance of the Liturgy clearly indicates that the Prayer was delivered by the priest at a time close

(106) Успенский, Литургия Преждеосвященных Даров..., 178.

(107) The Prayer, "O God, sitting on the Cherubim and Glorified by the Seraphim...," is present in the Slavonic manuscripts of the Presanctified Liturgy of the sixteenth century, for example, in the service books Sof. 556 (fol. 207r fol. 207v), Sol. 1023 (fol. 121v) from the collection of the National Library of Russia (the presence of the Prayer in the Sol. 1023 is mentioned in: A. А. Дмитриввский, Богослужение в русской церкви в XVI веке (Казань, 1884) 140).

(108) The service of Tritekti starts exactly with the Prayer "O God, sitting on the Cherubim and Glorified by the Seraphim...," which is entitled the Prayer of the first Antiphon in the manuscripts (see, for example, the Barberini $336-\mathrm{PA}^{-}$ Renti, VelkovsкA, L'eucologio Barberini..., 87, the Sinai 957 - ДМИтрИЕвскиЙ, Описание литургических рукописей..., т. 2, 9).

(109) For example, on fol. 70v of the Greek Codex № 213 from the Paris National Library (Дмитриввский, Описание литургических рукописей..., т. 2, 1003), on fol. 115v.-116r of the Slavonic Trebnik Syn. 675 from the State Museum of History, that contains the prayers of the "asmatike akolouthia" (for the Slavonic manuscripts, see: Е. П. ДиАковский, Чин тритекти (Киев, 1908) 9). 
to the transfer of the Gifts, apparently, during the singing of "Now the hosts of heaven invisibly worship..." In the manuscript Khlud. 117, before the text of "O God, sitting on the Cherubim and Glorified by the Seraphim...," it says: "нй'Е сили нЕеєнил", followed by: “и Поставить

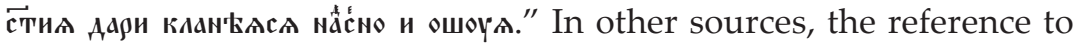
the singing of the Hymn "Now the hosts of heaven invisibly worship..." also precedes the Prayer "O God, sitting on the Cherubim and Glorified by the Seraphim..."

This is the text of "O God, sitting on the Cherubim and Glorified by the Seraphim...," according to the manuscripts Khlud. 117 and Uvar. 46: ${ }^{110}$

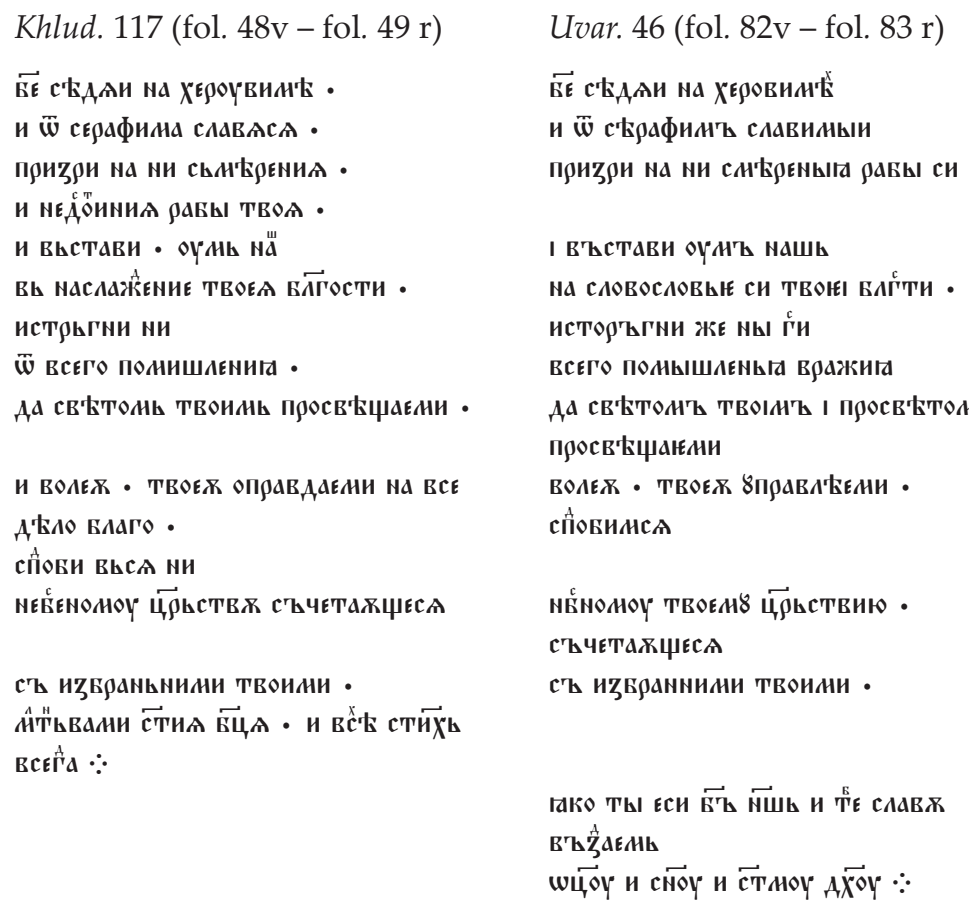

(110) The text of the prayer, "O God, sitting on the Cherubim and Glorified by the Seraphim...," from the Syn. typ. 40 and Syn. typ. 43 can be found in the Appendix on p. 64. The Greek text of this prayer from the ordinance of the Tritekti is published by А. А. ДмитриЕвский according to the Sinai 957 (Onuсaние литургических рукописей..., т. 2, 9), and Parenti, Velkovsкa, L'eucologio Barberini..., 87, 88 according to the Barberini 336 (see also: M. АрРАНЦ, Как молились Богу древние византийць: Суточный круг богослужения по древним спискам Византийского Евхология (Дисс., Денинград, Денинградская духовная академия, 1979) 223). 
Although the Prayer "O God, sitting on the Cherubim and Glorified by the Seraphim...," is included in the ancient Cathedral service of Constantinople both in the service of the First Hour, and as the initial prayer of the Tritekti, the source of the appearance of the Prayer in the Presanctified Liturgy is undoubtedly the rite of Tritekti. This service was a part of the daily circle of the Cathedral service during Great Lent, and was closely associated with the Liturgy of the Presanctified Gifts, which, according to Simeon of Thessaloniki, was never performed without the Tritekti in the Church of Hagia Sophia in Constantinople. ${ }^{111}$ The manuscripts of the Typikon of the Great Church provide instructions on the performance of the Tritekti on Wednesday and Friday of Cheese-fare Week, during Great Lent, Holy Thursday and Holy Friday. ${ }^{112}$

The liturgical term "Tritekti" was used in the Slavonic liturgical manuscripts to denote the Lenten service of the Third and the Sixth Hour, but we do not know of any Slavonic manuscripts of the Tritekti service. ${ }^{113}$ Nevertheless, since we do not have evidence on performance of the Slavonic service of Tritekti, and the Greek Euchologia contain the Prayer "O God, sitting on the Cherubim and Glorified by the Seraphim..." in the ordinance of the Presanctified Liturgy, the question of whether "O God, sitting on the Cherubim and Glorified by the Seraphim..." found its way into the Slavonic manuscripts of the Presanctified Liturgy from the Greek Liturgy, or was borrowed by the compiler of the Slavonic service directly from the rite of the Tritekti, remains unsettled.

The Russian service book Q.p. I.67 requires reading the Prayer “ $\overrightarrow{\mathbf{E} \varepsilon}$

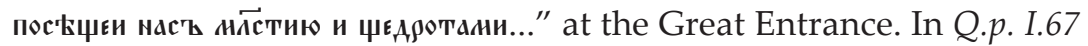
it bears the title мйта пртнос⿰у (fol. 71r). This prayer is present in the manuscripts of the Liturgy of Apostle James ${ }^{114}$ and is one of the few liturgical elements recorded by early Slavonic manuscripts that go

(111) On the service of Tritekti in Symeon of Thessaloniki, see: PG 155, cols. 649-753.

(112) Mateos, Le Typikon de la Grande Église..., 4, 72, 78, 292, 293; ДмитриЕвский, Аревнейшие патриаршие Типиконы..., 137, 324. In Great Thursday, after the Tritekti, the full Liturgy was performed.

(113) Greek manuscripts, related to the rite of Tritekti, are listed in the study of АрРАнц, Как молихись Богу древние византийцьы..., 231-238.

(114) B.-Ch. Mercier, La Liturgie de S. Jaques. Edition critique, avec traduction latine (Paris, 1946) (PO, 26.2) 190-192. 
back to this Liturgy. ${ }^{115}$ The question of the impact of the Liturgy of Apostle James on the Slavonic Liturgy requires a separate study. The greatest interest represent the cases, where for the Slavonic liturgical element from the Liturgy of the Apostle James it is not possible to find a corresponding Greek intermediary, that is, a document prior to the Slavonic manuscripts, that contains the element of the Liturgy of the Apostle James in the same place of the liturgical ordinance

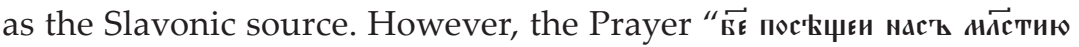
и чедлотании..." does not belong to such cases. The intermediaries, through which the Prayer found its way into the Q.p. I.67, most certainly were the manuscripts of the Greek Liturgy of the Presanctified Gifts. Muraitis mentions six Euchologia in this connection. ${ }^{116}$ Three of them (11th century Paris. gr. 391, 14th century Paris. gr. 328, 14th-15th century Paris. gr. 324 from the Paris National Library), contain both the Prayer "Master and Lord, who visit us in mercy and compassion...," and the Prayer "O God of ineffable and unseen mysteries..." that follows the Great Entrance. In the other three Euchologia, the Sinai Euchologion of the twelfth century Syn. 973, Syn. 971 of the thirteenth-fourteenth century, and the manuscript № 177 from the Philotheus Monastery on Mount Athos, the Prayer "O God of ineffable and unseen mysteries..." is absent.

This is the text of the Prayer "Master and Lord, who visit us in mercy and compassion..." from the Q.p. I.67 (fol. 71v - fol. 73r):

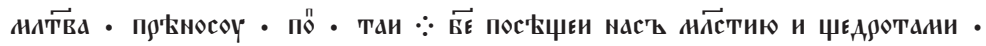
в

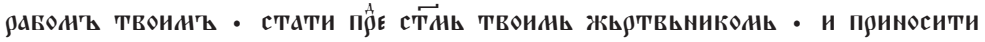

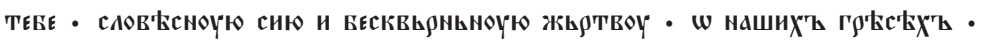

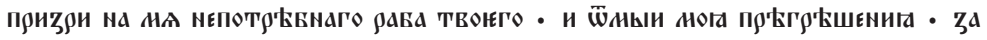

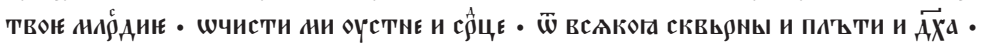

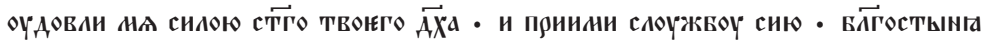

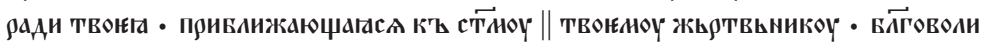

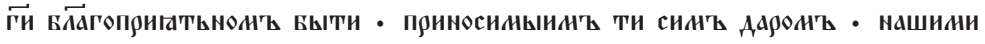

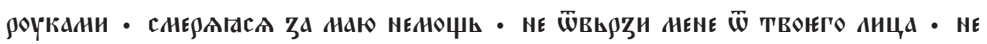

(115) A detailed (but not complete) list of instances, where the elements borrowed from the Jerusalem Liturgy of Apostle James, appear in Slavonic liturgical sources, can be found in: С. Муретов, Исторический обзор чинопоследования проскомидии до «Устава Аитургии» Константиноподьского патриарха Филофея (отдельный оттиск статей из Чтений в обществе любителей духовного просвещения за 1893, 1894 г.) (Москва, 1896) 225-229.

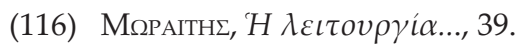




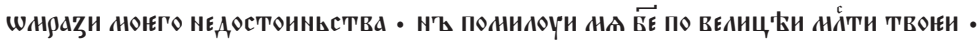

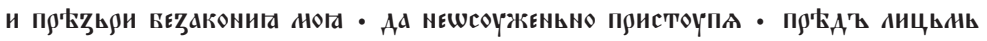

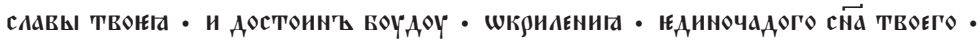

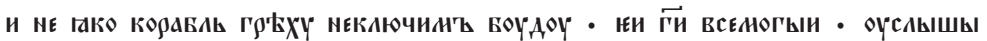

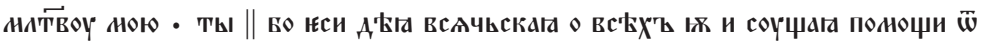

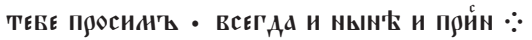

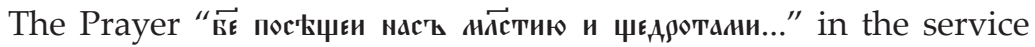
book Q.p. I.67 almost entirely corresponds to the Prayer of the Presanctified Liturgy from the earliest of known Greek sources, the manuscript Paris. gr. 391 ${ }^{117}$. The text of this Prayer in the manuscripts of the Liturgy of Apostle James in several places supplements the Paris. gr. 391, ${ }^{118}$ but these additions are not reflected in the Q.p. I.67, which is further evi-

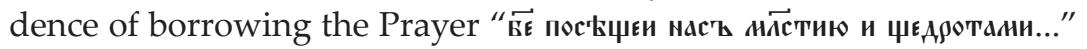
not from the Liturgy of Apostle James, but from the Greek Liturgy of the Presanctified Gifts.

\section{Dialogue of the Clergy}

In the manuscript Khlud. 117, the Prayer "O God, sitting on the Cherubim and Glorified by the Seraphim..." and the rubric и поставить стин дали клан'Асл наясно и ошоүл are followed by the dialogue between the priest and the deacon, which usually finishes the ordinance of the Great Entrance at the Liturgy of John Chrysostom and the Liturgy of Basil the Great. The existence of this dialogue in the ordinance of the Presanctified Liturgy is the unique feature of the manuscript Khlud. 117. We do not know about other Slavonic and Greek manuscripts or printed editions that contain the dialogue between the priest and the deacon in the text of the Liturgy of the Presanctified Gifts after the transferring of the Holy Gifts to the Holy Table.

This is the text of the dialogue, along with the dialogue from the Liturgy of Basil the Great from the same manuscript Khlud. 117:119

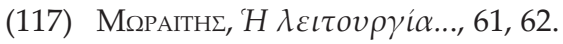

(118) See: Mercier, La Liturgie de S. Jaques..., 190, 192.

(119) There are substantial differences between the dialogues from the Liturgy of Basil the Great and the Presanctified Liturgy in the Khlud. 117, however, this is the usual case in the early manuscript tradition. The presence of different forms of dialogue in the formulas of the Liturgies of John Chrysostom and Basil the Great in the same Codex is known both from the Greek (cM. R. TAfт, The Great Entrance (Rome, 1975) (Orientalia Christiana Analecta, 200) 299) and Slavonic sources (see: А. С. Слуцкий, Диалог священнослужите- 
Liturgy of Basil the Great

(fol. 27r)

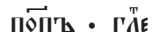

БАГัОАОВИТТ СЁЧЕННИ •

3

Ай́์ •

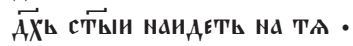

и сила вишьнаго

6

осьнить ТА вйко •

Аุห้ •

ПоНАNИ НА ВЙКО .

9
Liturgy of the Presanctified Gifts

(fol. 49r)

ГӒ сиЕ .

БСГГАОВИТЕ СТТ̈И •

Aй́r •

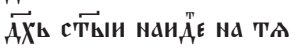

ппь •

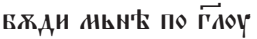

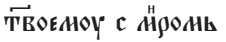

In the written sources of the Liturgies of John Chrysostom and Basil the Great, the dialogue appears initially in very brief form starting in the tenth century. In more complete form, similar to the dialogue from the Khlud. 117, it can be found in the Euchologia, starting from the twelfth century. ${ }^{120}$ Since the service book Khlud. 117 is dated to the last quarter of the thirteenth century, ${ }^{121}$ that is, to the time close to the emergence of the developed forms of the dialogue in the Byzantine sources, the phenomenon of the emergence of the dialogue in the Liturgy of the Presanctified Gifts requires special consideration, since it may be important for the study of the origin of the dialogue as a part of the Liturgy.

The form of the dialogues in the Khlud. 117 substantially differs from the version, contained in the printed sources until recently. In contrast to the dialogues from the Khlud. 117, the key phrase from the dialogue in the Liturgy of John Chrysostom, contained in the printed service book, "The Holy Spirit will come upon you, and the power of the Most High will overshadow you" (Lk. 1, 35) is pronounced by the deacon and is addressed to the priest. ${ }^{122}$ However, in the manuscript sources of the thirteenth-fourteenth centuries, both variants of the distribution of roles in the dialogue can be found. In order to clarify the specific

лей после Великого Входа в славянских служебниках XIII-XIV веков, ХВ 2 (VIII) (2000) 245, 250, 251, manuscript O.p. I.5).

(120) Seе: Слуцкий, Диалог священнослужителей..., 243.

(121) See, note 43.

(122) Seе: Слуцкий, Диалог священнослужителей..., 253. 
features of the dialogues in Khlud. 117 in comparison to the manuscripts that belong to the same period, it is necessary to explore the dialogue from the Liturgies of John Chrysostom and Basil the Great in the Slavonic manuscripts of the thirteenth and fourteenth centuries. Comparison of the Khlud. 117 with the manuscripts of the thirteenth and fourteenth centuries shows that the distribution of roles in the dialogue which is recorded in the Khlud. 117, coincides with the distribution of roles recorded in most of these sources. However, the dialogues in Khlud. 117 have some specific features which do not correspond to the text of the dialogue in other manuscripts. First of all, the dialogue in the Liturgy of the Presanctified Gifts from the Khlud. 117, lacks the deacon's petition that follows Lk.1, 35 and is contained in all other sources of the thirteenth and fourteenth centuries (lines 7, 8 of the dialogue from the Liturgy of Basil the Great). Second, in both other dialogues from the manuscript Khlud. 117, the traditional response of the priest to this petition from the service books of the thirteenth and fourteenth centuries, "Let the Lord remember you...," is absent. ${ }^{123}$ Instead, the phrase is cited in the dialogue from the Liturgy of Basil the Great, which does not occur in other service books (lines 10,11). Thirdly, the phrase, "May it be to me as you have said..." (Lk. 1, 38) from the dialogue in the Presanctified Liturgy (lines 10,11) completes the dialogue in other service books of the thirteenth and fourteenth centuries, and belongs not to the priest, but to the deacon. The only exception is the dialogue in the Liturgy of Basil the Great from the manuscript O.p. I.5, where the phrase "May it be to me as you have said..." occupies the same place as in the Khlud. 117. ${ }^{124}$

Thus, the text of the dialogue from the Liturgy of the Presanctified Gifts that is contained in the manuscript Khlud. 117, is generally consistent with the text of the dialogue from the Liturgies of John Chrysostom and Basil the Great in the Slavonic manuscript tradition of the thirteenth-fourteenth centuries. The differences from the most common forms of dialogue in these sources usually also occur in other manuscripts. The most significant feature of the dialogue from the Liturgy of the Presanctified Gifts, as compared to other versions of the thirteenth and fourteenth centuries, is its more concise form. The abbreviated record of the dialogue in the Presanctified Liturgy can indicate that the dialogue in its oral form was originally present in this

(123) Seе: Слуцкий, Диалог священнослужителей..., 245.

(124) See Ibid., 251. 
Liturgy. Thus, the presence of the dialogue in the Khlud. 117 may be a trace of an ancient tradition, but the absence of other evidence relating to the dialogue in the Presanctified Liturgy makes it more plausible that the addition of dialogue to the Liturgy of the Presanctified Gifts in the Khlud. 117 represents a local tradition that did not enjoy widespread occurrence.

\section{COMMUNION}

\section{Preparation for Communion}

After the Great Entrance and placing the Gifts on the Holy Table, the preparation for Communion begins. The deacon pronounces the Litany of Supplication, "Help us, save us, have mercy upon us and keep us, O God...," followed by the general Prayer "Our Father...," two silent Prayers of the priest, "O God, alone good and compassionate...," and "Give heed, Lord Jesus Christ our God...," and the exclamation, "The presanctified Holy Gifts for the holy people of God." The presentation of this part of the ordinance in the earliest Slavonic manuscripts of the Presanctified Liturgy generally coincides with the modern ordinance. As a particular feature of this part of the service in the Old Russian recension, we should note the text which is contained in the service books Sof. 521, Syn. 892 and O.p. I.4. This text describes the exclamation of verse 17 of Psalm 50 before the prayer, "Give heed, Lord Jesus Christ our God...":

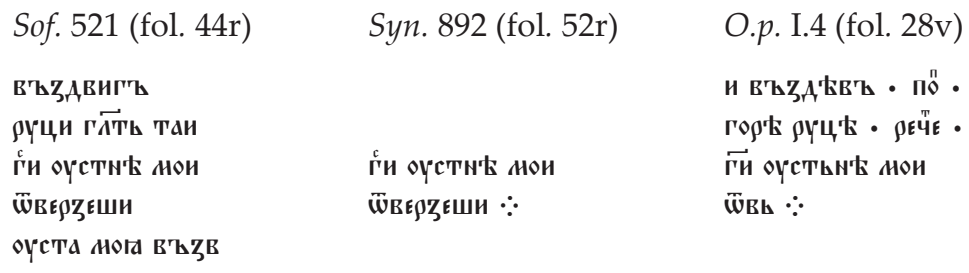

In modern liturgical practice, Psalm 50, 17 ("Lord, open my lips, and my mouth shall declare your praise...") is pronounced by the priest before the beginning of the Liturgies of John Chrysostom and Basil the Great, ${ }^{125}$ and by the reader in the beginning of the Matins, before reading the Six Psalms. ${ }^{126}$ The instruction of the service books O.p. I.4 and

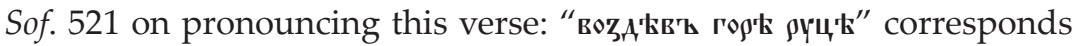

(125) Служебник, ч. 1 (Москва, 1991) 94.

(126) Часослов (Москва, 1980) 43. 